UDC: $615.451 .2: 546.46: 615.014 .471: 615.014 .83$

DOI: $10.15587 / 2519-4852.2019 .165650$

\title{
SELECTION OF FLAVORING AGENTS AND PRIMARY PACKAGING FOR THE COMBINED ORAL SOLUTION NAMED «MAGLYCIMET»
}

\author{
C D. Snehyrova, L. Almakaeva
}

\begin{abstract}
Мета. На основі теоретичних та експериментальних досліджень обрати коригенти смаку і первинне пакування для комбінованого орального розчину під умовною назвою «Магліцимет» на основі солей магнію аспарагінату, магнію глутамінату, глічину і метилкобаламіну.

Методи. У дослідженнях використовували органолептичні, фізико-хімічні, фармако-технологічні методи згідно вимог Державної Фармакопеї Украӥни та Європейської Фармакопеї.

Результати. Для надання препарату приємних органолептичних характеристик нами були досліджені серії отриманого розчину з різними коригентами та їх концентрачіями. При виборі підсолоджувача вивчали натрію цикламат у кількості 0.05-0.15\%; натрію сахаринат у кількості 0.05-0.15\%; натрію сахаринат і сорбітол в таких співвідношення: 0.1 i $5 \%, 0.1$ і $8.5 \%$, 0.15 і $10 \%$; сахарозу у кількості 20-30\%. Дослідження проводили на основі методик А.І. Тенщової та І.А. Сгорова в три окремих етапи. На першому етапі отримали 12 серій розчину з різними підсолоджувачами, з яких до другого етапу пройшли чотири. На третьому етапі на підставі оцінок групи добровольщів обирали найкращий. Ним виявився натрію сахаринат у кількості $0.1 \%$. Для вибору ароматизатора досліджували такі: «вишня», «малина», «персик» в кількості від 0.1 до $1.0 \%$ В результаті досліджень було визначено, щуо найкращими смаковими якостями володів зразок з ароматизатором «вишня» у кількості $0.6 \%$ При визначенні первинного пакування досліджували дозволені в Україні флакони по 100 мл з помаранчевого скла і поліетилентерефталату (двох типів). Проводили контроль основних показників якості досліджуваних зразків після 3, 6, 9, 12, 18 місяців зберігання у флаконах. Встановлено, щуо всі види пакування не викликали змін основних показників якості розчину, щзо виходять за межі проекту методів контролю якості. Це дозволяє рекомендувати всі види досліджуваних флаконів.
\end{abstract}

Висновки. На підставі теоретичних та експериментальних досліджень для комбінованого орального розчину під умовною назвою «Маглічимет» обрані підсолоджувач натрію сахаринат у кількості $0.1 \% i$ ароматизатор «вишня» у кількості $0.6 \%$. В якості первинного пакування рекомендуються всі види досліджених флаконів: з помаранчевого скла і поліетілентерефталату (двох типів)

Ключові слова: оральний розчин, солі магнію, корекція смаку, первинне пакування

\section{Introduction}

Each medicine contains not only active pharmaceutical ingredients (API), but also auxiliary substances (AS). Many factors can affect the stability of a medicine, including $\mathrm{pH}$, temperature, solvent, light, oxygen, carbon dioxide. The purpose of AS utilization is determined by their physico-chemical properties and is associated with complex interactions within the composition of the dosage form, the influence of the external environment on it, the characteristics of the production process. The exact choice is established in the context of each particular medicine, taking into account all the above mentioned factors.

One of the most important characteristics of a medicine is its taste and smell, especially for syrups and oral solutions. Various unpleasant taste of the active ingredients in the composition of medicines - bitter, salty, sour, sweet, alkaline, metal - significantly reduce the compliance of patients to treatment. Therefore, an important technological aspect in the development of medicines in these dosage forms is giving them pleasant organoleptic characteristics with the help of special auxiliary substances - corrective agents of taste and smell.
Sweeteners and flavoring agents are used as corrective agents. At the stage of medicine development, along with the correction of taste and smell, it is necessary to consider the stability of the dosage form as a whole, i.e. compatibility of all active and auxiliary substances. Corrective agents should have a pleasant taste, smell and color; mix well with other substances of the composition, do not reduce medicine activity and stability, be indifferent or beneficial to the body, stable in a certain $\mathrm{pH}$ range, resistant to light, oxidation and reduction.

We have developed a combined oral solution based on magnesium aspartate and magnesium glutamate. The amino acid glycine and vitamin $\mathrm{B}_{12}$ methylcobalamin were also added. Magnesium is a macroelement and plays a fundamental role in many cellular functions, including energy production, neurochemical transmission, skeletal and cardiac muscle excitability, normal intracellular calcium, sodium and potassium levels, insulin secretion, bone formation, synthesis of carbohydrates, proteins, lipids, nucleic acids and others. Magnesium deficiency is one of the factors for the development of many diseases $[1,2]$. The tendency to an increase of an 
element insufficiency throughout the world is a topical issue of world society [3, 4].

The choice of the dosage form - oral solution possess several advantages: high bioavailability of API, ease of usage compared to tablets and injection forms, the ability to mask the unpleasant smell and taste of ingredients, which is a benefit in pediatric and geriatric practice. Moreover, such liquid dosage forms are convenient for manufacturing.

2. Formulation of the problem in a general way, the relevance of the theme and its connection with important scientific and practical issues

In the process of medicines development an integrated approach to the choice of corrective agents is necessary: on the one hand, they should provide their function in the form of imparting pleasant organoleptic characteristics to the medicine, and on the other hand, they should be harmless and compatible with other components. Taste masking is based on suppressing the undesirable taste of individual components by introducing substances with stronger taste impulses.

The APIs of the developed medicine are magnesium salts with aspartic and glutamic acids, glycine. They possess specific bitter taste. Therefore, the selection of corrective agents - sweeteners and flavoring agents was an important stage of technological research.

Another important aspect for the oral solution development was the selection of suitable primary packaging. For this purpose, we should take into account the physicochemical properties of the combination of active and auxiliary substances in the selected dosage form. Primary packaging should ensure the stability of the medicine during storage, be sealed, convenient during transportation and utilization.

\section{Analysis of recent studies and publications in} which a solution of the problem are described and to which the author refers

A group of scientists from Duke University in North Carolina investigated the taste sensations caused by the application of various medicines on the surface of the patient's tongue. Among over 60 tested medicines were drugs against AIDS, hypertension and depression treatment. Scientists identified those groups of medicines that need emergency measures to improve their taste [5]. The article by Susan S. Schiffman summarizes various data on the frequency of chemosensory disorders that occur after the use of different medicines. Such phenomena as ageusia (complete loss of taste), dysosmia (distortion of smell) and many others may occur after taking medicines with unpleasant organoleptic characteristics [6]. In the investigation of oral gels with an unpleasant aftertaste (gel of glycine based on a derivative of cellulose) and a pronounced unpleasant odor and bitter taste (gel based on ibuprofen derivative of acrylic acid) using the method of A.I. Tentsova next corrective agents were selected: in the first case - mannitol and vanillin, in the second - aspartame and a combination of flavoring agents [7]. Literature data suggest that the introduction of corrective agents is a necessary technological aspect and is solved in each specific case.
Several authors provide an overview of the various primary packaging for liquid dosage forms, and indicate factors affecting their choice and stability [8,9]. There are also studies of primary packaging for specific oral medications. For example, for ammonium chloride and diphenhydramine chloride syrup, the suitability of polyethylene, polypropylene and glass vials was studied based on quality indicators after accelerated aging [10]; for an oral solution, based on arginine asparaginate, studies on stability in orange glass, glass and polyethylene vials were provided [11].

\section{The field of research considering the general problem, which is described in the article \\ An important task in the process of pharmaceuti-} cal development is the correction of taste of each specific medicine, since it has its own specific composition of active pharmaceutical ingredients, auxiliary substances and the dosage form. The choice of corrective agents in the case of oral solutions requires not only correcting its organoleptic characteristics, but also the simultaneous study of the effect of corrective agents on the biological activity of the composition and the stability of the dosage form during storage.

The choice of primary packaging must be justified by data on the study of the medicine stability during the shelf life. Each product contains a specific composition of the main active and auxiliary substances, which requires the individual selection of packaging in each case.

\section{Formulation of goals (tasks) of article}

To choose corrective agents and primary packaging for the combined oral solution named «Maglycimet», which consist of magnesium aspartate, magnesium glutamate, glycine and methylcobalamin, based on theoretical and experimental investigations.

\section{Presentation of the main research material (methods and objects) with the justification of the results}

The objects of research were the obtained series of the combined oral solution named «Maglycimet». The medicine composition includes the following APIs: magnesium aspartate, magnesium glutamate, glycine, methylcobalamin. All substances met the requirements of the State Pharmacopoeia of Ukraine (SPHU) [12] and the European Pharmacopoeia (EP) [13]. Methylcobalamin met the requirements of the Japanese Pharmacopoeia [14]. As auxiliary substances antioxidants, sweeteners, and preservatives that are generally accepted in the technology of oral solutions preparing were used. Their quality corresponded to the requirements of the EP [13]. Food flavoring agents «cherry», «raspberry», «peach» corresponded to TU U 15.8-23788752-001-2001. Solvent purified water - met the requirements of SPHU [15]. The preparation of the experimental series of the «Maglycimet» oral solution was carried out in the research laboratory of parenteral and oral liquid medicines of the $\mathrm{Na}$ tional University of Pharmacy.

Organoleptic, physicochemical, and pharmacotechnological methods according to the requirements of SPHU [12] and EP [13] were used during the research. The $\mathrm{pH}$ of the medium was measured by a potentiometric meth- 
od according to SPhU, 2.2.20. [12]. Quantitative determination of magnesium was performed by the complexometric method, SPHU, 2.5.11. [12], glycine and methylcobalamin - by HPLC, SPHU, 2.2.29. [12]. All the laboratory and analytical equipment passed metrological certification.

Corrective agents belong to substances that are added to medicines in order to give them pleasant taste and smell. Such organoleptic properties of medicines are acceptable, which flavoring effect appears quickly and to the fullest extent, do not have aftertaste and unpleasant sensations.

One of the most commonly used in the pharmaceutical industry groups of corrective agents is sweeteners. Sweeteners are substances that make medicines taste sweet. They are classified according to their origin (natural or synthetic), caloric level (high-caloric, low-caloric, practically non-caloric), degree of sweetness (high or low sweetness factor $\mathrm{K}_{\mathrm{s}}$ ), chemical composition, etc. [16-19]. The most common are traditional sweeteners, such as sucrose, glucose, fructose, sorbitol, and more intense sodium cyclamate, saccharin sodium, etc. The table shows the sweeteners, based on their sweetness ratios (Table 1).

Table 1

Sweetness factors for different sweeteners

\begin{tabular}{|c|l|c|}
\hline No. & Sweetener & Sweetness factor $\mathbf{~ K}_{\mathbf{s}} \mathbf{~}$ \\
\hline 1 & \multicolumn{1}{|c|}{ Traditional } \\
\hline \multicolumn{2}{|c|}{} \\
\hline 1. & Mannitol & 0.6 \\
\hline 2. & Sorbitol & 0.5 \\
\hline 3. & Glucose & 0.5 \\
\hline 4. & Sucrose & 1.0 \\
\hline 5. & Fructose & 1.2 \\
\hline 6. & Xylitol & 1.0 \\
\hline \multicolumn{2}{|c|}{ Intense } \\
\hline 1. & Sodium cyclamate & 30 \\
\hline 2. & Potassium acesulfame & 200 \\
\hline 3. & Aspartame & 200 \\
\hline 4. & Saccharin sodium & 450 \\
\hline 5. & Neotam & 8000 \\
\hline
\end{tabular}

Sorbitol is currently the most common sweetener in pharmaceutical practice. But it possesses low potential of sweetness, and that is why sorbitol is added to dosage forms in large quantities, which causes certain difficulties in industrial production.

We have developed samples of oral solution with magnesium aspartate and magnesium glutamate, glycine, methylcobalamin and antioxidant sodium metabisulphite to conduct research on the choice of sweetener. Sweeteners were introduced into the samples in various concentrations. The assessment of taste was made by the method of A. I. Tentsova (determination of numerical indexes). The method is characterized by the basic taste of the substance. The degree of basic taste is determined in points from 0 to 5 . Also the method for taste assessing using alphabetic and numeric indices (method of I.A. Egorov) was used. In this acse the most important qualitative signs of the medicine are evaluated by alphabetic and numeric indices constituting the «taste panel», which later helps to record the general formula of medicine taste. The sense of taste is conventionally denoted by letters: S stands for sweet, B - bitter, S - salty, SR sour; and digital indices:

1 - not sweet, not bitter, not salty, not sour;

2 - slightly sweet, slightly bitter, slightly salty, slightly sour;

3 - sweet, bitter, salty, sour; $[20,21]$.

4 - very sweet, very bitter, very salty, very sour

In order to choose the sweetener were carried out next investigations in several separate stages. The best composition was proved according to the given methods. At the first stage 12 series of oral solution with various sweeteners and their concentrations were obtained, namely with: sodium cyclamate with concentrations $0.05-0.15 \%$; saccharine sodium with concentrations $0.05-0.15 \%$; saccharin sodium and sorbitol in such ratios: 0.1 and $5 \%, 0.1$ and $8.5 \%, 0.15$ and $10 \%$; sucrose with concentrations $20-30 \%$. Four of them were selected to the second stage. At the third stage the best one was chosen. The results of the final studies are shown in Table 2.

Based on the data presented in Table 2, the composition of the oral solution with different sweeteners was similar in taste characteristics. However, in terms of numerical value, composition No.3 was preferred. Saccharin sodium in the amount of $0.1 \%$ was chosen as a sweetener. It belongs to the group of intense synthetic sweeteners and is 300 times sweeter than sucrose. Its concentration in the composition of oral dosage forms varies from 0.04 to $0.25 \%$. The main advantage of saccharin sodium utilization is the possibility of using the developed medicine for patients with diabetes.

Flavoring agents were also investigated to improve the taste of the oral solution dosage form based on amino acid salts of magnesium.

As flavoring agents «cherry», «raspberry» and «peach» was chosen for research. According to the previous studies the composition of the oral solution with saccharin sodium $(0.1 \%)$ as sweetener was used as a sample to determine the most suitable flavoring agent and its quantity. We investigated the above mentioned substances in the range of concentration from $0.1 \%$ to $1.0 \%$.

The food flavoring agent was selected using an organoleptic taste assessment from the point of view of objective sensations according to this system: 5 - very pleasant, 4 - pleasant, 3 - not bad, 2 - bad, 1 - very bad. As a result of research, based on the findings of a group of 20 volunteers, the sample of the oral solution with the addition of «cherry» flavoring with concentration $0.6 \%$ had the best taste.

Table 3 shows the composition of the oral solution, taking into account the selected corrective agents. 
Influence of corrective agents on oral solution taste changing

\begin{tabular}{|c|c|c|c|c|c|}
\hline \multirow{3}{*}{ No. } & \multirow{3}{*}{ Sample composition (g) } & \multicolumn{4}{|c|}{ Taste Evaluation Techniques } \\
\hline & & \multicolumn{2}{|c|}{ According to A.I. Tentsova } & \multicolumn{2}{|c|}{ According to I.A. Egorov } \\
\hline & & $\begin{array}{l}\text { Taste sensation } \\
\text { (point) }\end{array}$ & $\begin{array}{c}\text { A sense of basic } \\
\text { taste (point) }\end{array}$ & $\begin{array}{c}\text { Formula of } \\
\text { taste }\end{array}$ & Overall taste \\
\hline 1 & 2 & 3 & 4 & 5 & 6 \\
\hline 1 & $\begin{array}{l}\text { Magnesium L-aspartate }-8.313 \\
\text { Magnesium L-glutamate }-3.932 \\
\text { Glycine }-1.000 \\
\text { Methylcobalamin }-0.00025 \\
\text { Sodium metabisulphite }-0.150 \\
\text { Sucrose }-30.000 \\
\text { Potassium sorbate }-0.150 \\
\text { Purified water up to } 100 \mathrm{ml}\end{array}$ & 3.7 & 3.8 & S3 & Sweet \\
\hline 2 & $\begin{array}{l}\text { Magnesium L-aspartate }-8.313 \\
\text { Magnesium L-glutamate }-3.932 \\
\text { Glycine }-1.000 \\
\text { Methylcobalamin }-0.00025 \\
\text { Sodium metabisulphite }-0.150 \\
\text { Saccharin sodium }-0.150 \\
\text { Potassium sorbate }-0.150 \\
\text { Purified water up to } 100 \mathrm{ml} \\
\end{array}$ & 3.4 & 3.6 & B1S4 & $\begin{array}{c}\text { Slightly bitter, } \\
\text { very sweet }\end{array}$ \\
\hline 3 & $\begin{array}{l}\text { Magnesium L-aspartate }-8.313 \\
\text { Magnesium L-glutamate }-3.932 \\
\text { Glycine }-1.000 \\
\text { Methylcobalamin }-0.00025 \\
\text { Sodium metabisulphite }-0.150 \\
\text { Saccharin sodium }-0.100 \\
\text { Potassium sorbate }-0.150 \\
\text { Purified water up to } 100 \mathrm{ml}\end{array}$ & 4.4 & 4.6 & S3 & Sweet \\
\hline 4 & $\begin{array}{l}\text { Magnesium L-aspartate }-8.313 \\
\text { Magnesium L-glutamate }-3.932 \\
\text { Glycine }-1.000 \\
\text { Methylcobalamin }-0.00025 \\
\text { Sodium metabisulphite }-0.150 \\
\text { Sodium cyclamate }-0.100 \\
\text { Potassium sorbate }-0.150 \\
\text { Purified water up to } 100 \mathrm{ml}\end{array}$ & 4.2 & 4.4 & S3 & Sweet \\
\hline
\end{tabular}

Table 3

The oral solution named «Maglycimet» composition

\begin{tabular}{|l|c|c|}
\hline \multicolumn{1}{|c|}{ Compound } & Quantity, $\mathbf{g} / \mathbf{1 0 0} \mathbf{~ m l}$ & Role \\
\hline Magnesium L-aspartate & 8.312 & API \\
\hline Magnesium L-glutamate & 3.932 & API \\
\hline Glycine & 1.000 & API \\
\hline Methylcobalamin & 0.00025 & API \\
\hline Sodium metabisulphite & 0.150 & Antioxidant \\
\hline Saccharin sodium & 0.100 & Sweetener \\
\hline Potassium sorbate & 0.150 & Preservative \\
\hline Flavoring agent «cherry» & 0.600 & Flavoring agent \\
\hline Purified water & Up to $100 \mathrm{ml}$ & Solvent \\
\hline
\end{tabular}

The safety of the developed medicine in the course of storage, transportation and use by the patient is to a great extent ensured by the correctly chosen primary packaging. The choice of primary packaging must be confirmed in the process of scientific research for each medicine individually, since none of the types of materials is universal and indifferent to all substances and sol- vents. The main requirements for the design of primary packaging are the following: the ability to protect medicine from adverse environmental factors, protect it from mechanical effects, ensure tightness and stability, and protect against microbial contamination. Packaging materials and closures must be non-fragile, chemically inert, compatible with the components of the preparation. 
We have investigated the samples of primary packaging and closures that are available on the pharmaceutical market of Ukraine, registered in the Ministry of Health of Ukraine and are approved for use, namely: orange glass bottles of type FV 100-20-OS according to TU U 26.1-00480810-004: 2011, sealed with screw-on plastic lids of type 1.1-20 (from a mixture of high and low pressure polyethylene in proportions that prevent cracking at low temperatures and preserve rigidity and elasticity at high temperatures); polyethylene terephthalate (PET) bottles: type FP-100 according to TU U
25.2-34014330-001: 2008, complete with lids with first opening control (made of high-pressure polyethylene) and type FVP-100 according to TU U 26.1-19046619007: 2007, complete with a lid, providing tightness and control of the first opening.

The suitability of the primary packaging was checked after 3, 6, 9, 12, 18 months of storage.

Control was carried out according to the main indicators of quality according project of methods of quality control (MQC). The main results are presented in Table 4.

Table 4

Stability studies of oral solution in various types of primary packaging

\begin{tabular}{|c|c|c|c|}
\hline \multirow[b]{2}{*}{ MQC factors } & \multicolumn{3}{|c|}{$100 \mathrm{ml}$ bottles } \\
\hline & $\begin{array}{c}\text { Orange glass type FV } \\
100-20-\mathrm{OS}\end{array}$ & PET type FP-100 & PET type FVP-100 \\
\hline \multicolumn{4}{|c|}{ Colour (visually) (light pink) } \\
\hline Initial data & Complies & Complies & Complies \\
\hline 6 months & Complies & Complies & Complies \\
\hline 12 months & Complies & Complies & Complies \\
\hline 18 months & Complies & Complies & Complies \\
\hline \multicolumn{4}{|c|}{ pH (SPHU / Ph.Eur.,2.2.3.):(5.0-6.0) } \\
\hline Initial data & 5.38 & 5.38 & 5.38 \\
\hline 6 months & 5.40 & 5.40 & 5.42 \\
\hline 12 months & 5.42 & 5.42 & 5.44 \\
\hline 18 months & 5.43 & 5.42 & 5.44 \\
\hline \multicolumn{4}{|c|}{ Density (SPHU / Ph.Eur., 2.2.5.): 1.060-1.080 } \\
\hline Initial data & 1.073 & 1.074 & 1.074 \\
\hline 6 months & 1.074 & 1.074 & 1.075 \\
\hline 12 months & 1.075 & 1.074 & 1.074 \\
\hline 18 months & 1.074 & 1.074 & 1.075 \\
\hline \multicolumn{4}{|c|}{ Quantitative composition: } \\
\hline \multicolumn{4}{|c|}{ Glycine (SPHU / Ph.Eur., 2.2.29.): 9.50-10.50 mg/ml } \\
\hline Initial data & 9.838 & 9.840 & 9.848 \\
\hline 6 months & 9.835 & 9.836 & 9.836 \\
\hline 12 months & 9.833 & 9.834 & 9.833 \\
\hline 18 months & 9.832 & 9.831 & 9.832 \\
\hline \multicolumn{4}{|c|}{ Methylcobalamin (SPHU / Ph.Eur., 2.2.29.): $0.00225-0.00275 \mathrm{mg} / \mathrm{ml}$} \\
\hline Initial data & 0.00253 & 0.00254 & 0.00254 \\
\hline 6 months & 0.00253 & 0.00254 & 0.00253 \\
\hline 12 months & 0.00251 & 0.00252 & 0.00252 \\
\hline 18 months & 0.00250 & 0.00250 & 0.00250 \\
\hline \multicolumn{4}{|c|}{ Magnesium: (SPHU / Ph.Eur., 2.5.11.): 9.00-11.00 mg/ml } \\
\hline Initial data & 10.59 & 10.58 & 10.59 \\
\hline 6 months & 10.58 & 10.60 & 10.58 \\
\hline 12 months & 10.59 & 10.58 & 10.60 \\
\hline 18 months & 10.57 & 10.58 & 10.60 \\
\hline
\end{tabular}

It was established that the solution in all typed of bottles did not change the critical quality indicators and the analysis data corresponded to the limits of the MQC project.

\section{Conclusions}

1. The research for choosing corrective agents of taste and smell and primary packaging for the combined oral solution named «Maglycimet» was provided.

2. Corrective substances were selected as a result of investigation. Studying of various sweeteners and their quantitative combinations led to the selection of best option: saccharin sodium with concentration $0.1 \%$.
Among the investigated flavoring agents «cherry» agent with concentration $0.6 \%$ was selected.

3. Studies of oral solution in three types of primary packaging (bottles of orange glass and polyethylene terephthalate (two types)) showed the suitability of all the proposed options. This fact was confirmed by the results of determining the basic quality indicators after 3 , $6,9,12$ and 18 months of storage.

4. The research revealed the perspective of regulatory and technical documentation developing and, subsequently, of introducing the combined oral solution named «Maglycimet» into industrial production. 


\section{References}

1. Spasov A. A. Magniy v meditsinskoy praktike: monograph. Volgograd, 2000. 268 p.

2. Defitsit magniya kak problema stressa i dezadaptatsii u detey / Gromova O. A., Torshin I. Y., Grishina T. R., Fedotova L. E. // Russkiy meditsinskiy zhurnal. 2012. Vol. 20, Issue 16. P. 813-821.

3. DiNicolantonio J. J., O'Keefe J. H., Wilson W. Subclinical magnesium deficiency: a principal driver of cardiovascular disease and a public health crisis // Open Heart. 2018. Vol. 5, Issue 1. P. e000668. doi: http://doi.org/10.1136/openhrt-2017-000668

4. Al Alawi A. M., Majoni S. W., Falhammar H. Magnesium and Human Health: Perspectives and Research Directions // International Journal of Endocrinology. 2018. Vol. 2018. P. 1-17. doi: http://doi.org/10.1155/2018/9041694

5. Kuznetsov A. A., Kabakova T. I., Kuznetsov A. V. Udobstvo primeneniya kak ekonomicheskiy faktor optimizatsii ratsionalnogo ispolzovaniya lekarstvennyih sredstv // Fundamentalnyie issledovaniya. 2012. Vol. 10. P. 397-399.

6. Schiffman S. S. Influence of medications on taste and smell // World Journal of Otorhinolaryngology - Head and Neck Surgery. 2018. Vol. 4, Issue 1. P. 84-91. doi: http://doi.org/10.1016/j.wjorl.2018.02.005

7. Printsipyi korrektsii vkusa peroralnyih geley s sinteticheskimi lekarstvennyimi veschestvami / Anurova M. N., Bahrushina E. O., Pyatigorskaya N. V., Yambikova O. M. // Farmatsiya i farmakologiya. 2015. Vol. 4 (11). P. 15-20.

8. Campbell G. A., Vallejo E. Primary Packaging Considerations in Developing Medicines for Children: Oral Liquid and Powder for Constitution // Journal of Pharmaceutical Sciences. 2015. Vol. 104, Issue 1. P. 52-62. doi: http://doi.org/10.1002/jps.24223

9. Raina H., Jindal A. Packaging of Non-Injectable Liquid Pharmaceuticals: A Review // Journal of Applied Pharmaceutical Science. 2017. Issue 2. P. 248-257.

10. Singh K., Gupta R. Stability studies on a cough syrup in plastic containers // Indian Journal of Pharmaceutical Sciences. 2007. Vol. 69, Issue 3. P. 408-413. doi: http://doi.org/10.4103/0250-474x.34551

11. Almakaeva L. G., Begunova N. V., Almacaev M. S. Issledovaniya po vyiboru pervichnoy upakovki dlya oralnogo rastvora arginina asparaginata: processing. Tovaroznavchi aspekti spozhivchih tovariv. Kharkiv: Vid-vo NFaU, 2013. P. 9-10.

12. Derzhavna Farmakopeya Ukrayini. Vol. 1-3. Kharkiv: Derzhavne pidpriemstvo «Ukrayinskiy naukoviy farmakopeyniy tsentr yakosti likarskih zasobiv», 2014-2015. 1128 p., 724 p., 732 p.

13. European Pharmacopoeia. 9th Edition. European Directorate for the Quality of Medicines (EDQM). Strasbourg: Council of Europe, 2016. 4016 p.

14. Japanese Pharmakopeia 16-th ed. The Ministry of Health, Labour and Welfare, 2011-2014.

15. Voda ochyshchena // Derzhavna Farmakopeia Ukrainy. Dopovnennia 2. Kharkiv: Derzhavne pidpryiemstvo «Ukrainskyi naukovyi farmakopeinyi tsentr yakosti likarskykh zasobiv», 2014. P. 129.

16. Lyuk E., Yager M. Konservantyi v pischevoy promyishlennosti. Svoystva i primenenie. Saint Petersburg: GIORD, 2003. $256 \mathrm{p}$.

17. Buldakov A. S. Pischevyie dobavki: Handbook. Moscow: DeLi-print, 2003. 436 p.

18. Getalo O. V., Tsihotska O. O., Saliy O. O. Rozrobka siropu z magniyu hloridom i vitaminom B6 // Visnik farmatsiyi. 2005. Vol. 3. P. 59-61.

19. Sheryakova Yu. A., Hishova O. M. Podslastiteli v siropah i ih harakteristika. Vestnik farmatsii. 2014. Vol. 2. P. 106-111.

20. Tehnologiya likiv promislovogo virobnitstva / Chueshov V. I., Hohlova L. M., Lyapunova O. O., Sayko I. V., Gladuh E. V., Egorov I. A. et. al.; ed. by Chueshov V. I. Kharkiv: Zoloti storinki, 2003. 720 p.

21. Tentsova A. I. Aktualnyie voprosyi poiska i tehnologiya lekarstv. Kharkiv, 1981. 145 p.

Дата надходження рукопису 26.03.2019

Daria Snehyrova, Postgraduate Student, Junior Researcher, Department of Industrial Pharmacy, Scientific and Research Laboratory of Parenteral and Oral Liquid Medicines, National University of Pharmacy, Pushkinska str., 53, Kharkiv, Ukraine, 61002

E-mail: dsnegireva2017@gmail.com

Lyudmila Almakaeva, Doctor of Pharmaceutical Sciences, Professor Head of Laboratory, Scientific and Research Laboratory of Parenteral and Oral Liquid Medicines, National University of Pharmacy, Pushkinska str., 53, Kharkiv, Ukraine, 61002

E-mail: almakaeva@ukr.net 